\section{Ownership-motivated income shifting: evidence from European Multinational Groups}

\author{
Alice Medioli, Stefano Azzali and Tatiana Mazza \\ Department of Economics and Management, University of Parma, Parma, Italy
}

Income shifting in European groups

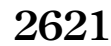

Received 10 August 2019 Revised 17 January 2020 Accepted 13 May 2020

\begin{abstract}
Purpose - Although tax-motivated income shifting has been widely explored, no studies have as yet analyzed the association between ownership structure and management decisions about income shifting. The ownership structure of multinational groups is characterized by different levels of minority interests, and our aim is to establish whether income shifting is explained by the aim of expropriation of minorities, as well as taxation avoidance.

Design/methodology/approach - We collect data on a sample of European parent companies located in five countries and their foreign subsidiaries, and run a multivariate regression based on the Huizinga and Laeven (2008) model.

Findings - Our results support the idea of minority expropriation, finding evidence of ownership-motivated income shifting. We also find that the level of minority protection affects ownership-motivated income shifting, and that, when both are present, expropriation is statistically significant.

Research limitations/implications - Although the study looks at a wide range of subsidiaries, a limitation may be that it examines only firms having parent companies in five European countries. Further research would overcome this limitation and extend the literature and take into account other income-shifting contextual variables. Our results may lead regulators to pay more attention to the protection of minority interests.

Practical implications - This research offers insights to companies and investors, and should help them to make better-informed decisions and evaluate the best contexts for investments.

Originality/value - This study enriches the literature on income shifting by revealing that it can be caused by factors other than the desire to avoid taxation. It suggests that ownership structure is crucial.
\end{abstract}

Keywords Ownership, Management decision, Income shifting decisions, European business groups

Paper type Research paper

\section{Introduction}

Income shifting is often performed by both companies and multinational groups to increase their net income and maximize the economic benefits of their shareholders. The literature has explored tax-motivated income shifting widely, but to the best of our knowledge, there are no studies that analyze the association between ownership structure and income shifting decisions. The ownership structure of multinational groups is characterized by different levels of minority interests, and our main hypothesis is that income shifting is driven by the expropriation of minority interests, as well as the desire to avoid taxation (see Figure 1).

The aim of our research is to study ownership-motivated income shifting in European Multinational Groups. We aim to establish whether ownership-motivated income shifting exists, whether it is restrained by the national level of minority protection and also whether it remains statistically significant even after controlling for the tax-motivated income shifting effect.

We analyze a sample of parent companies located in five significant European countries (Italy, France, Germany, Spain and the United Kingdom) and their foreign subsidiaries located in other European countries. Our findings confirm that European Multinational

(C) Alice Medioli, Stefano Azzali and Tatiana Mazza. Published by Emerald Publishing Limited. This article is published under the Creative Commons Attribution (CC BY 4.0) licence. Anyone may reproduce, distribute, translate and create derivative works of this article (for both commercial and noncommercial purposes), subject to full attribution to the original publication and authors. The full terms of this licence may be seen at http://creativecommons.org/licences/by/4.0/legalcode 


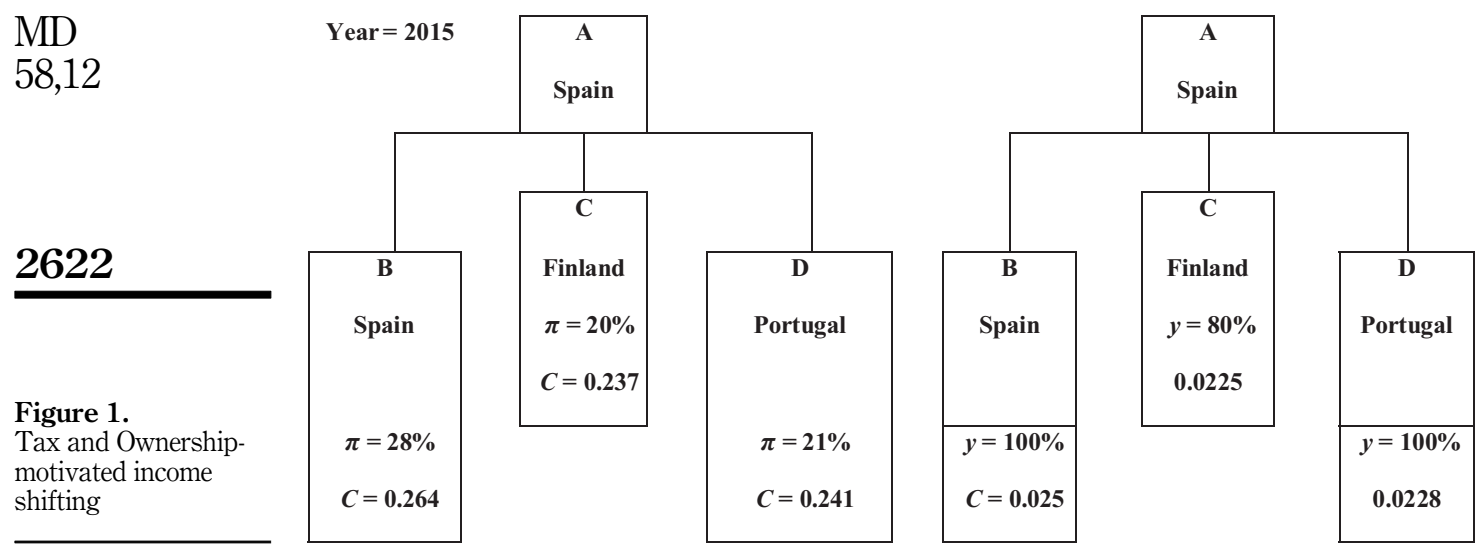

groups, when defining their income-shifting strategy, not only take into account tax motivation but also the aim to expropriate minorities. At the same time, ownership-motivated income shifting is moderated by the level of minority protection and remains statistically significant even after controlling for the tax-motivated income shifting effect.

Filling a gap existing in the literature, we contribute by suggesting that income shifting is not explained only by tax reasons, but there is also an explanation related to the expropriation of minority interests. Discovering that European Multinational Groups shift income, motivated by ownership structure, the study shows that the parent company has the incentive to shift income from the subsidiaries with a higher level of minority interests to the subsidiaries with a lower level of minority interests. Our second contribution is providing significant information useful for regulators by analyzing the effect of regulations protecting minority interests in European Multinational Groups. Showing that countries with a high level of minority protection are successful in limiting ownership-motivated income shifting, the study supports the importance of rules to protect minorities and prevent their expropriation. Third, we compare tax-motivated and ownership-motivated income shifting. Tax-motivated income shifting exists and is one of the main reasons for income shifting among subsidiaries in multinational groups, but it is not the only motivation.

The remainder of our study is organized as follows. Section 2 presents the literature review and hypothesis development. Section 3 describes the model and Section 4 presents the sample. Section 5 includes descriptive statistics and the correlation matrix, and Section 6 presents our main results. Section 7 is about robustness and Section 8 concludes.

\section{Literature review and hypothesis development}

\subsection{Ownership-motivated income shifting}

Literature defines entrenchment as a type of agency problem (Morck et al., 2005). Different researchers support the idea that when a company is part of a group, the business group rather than the individual company is the most appropriate "unit" for analyzing the organization and behavior of firms (Cainelli and Iacobucci, 2011; Chen and Chang, 2016; Shukla and Akbar, 2018).

Theoretical work on private benefits of control is well developed. Parties in control of a corporation are in a position to extract private benefits that do not accrue to dispersed shareholders. Faccio and Lang (2002) review the theory that control provides large private benefits (see, for example, Barclay and Clifford, 1989; Jensen and Meckling, 1976; Johnson et al., 2000a, b; Almeida and Wolfenzon, 2006). Exploitation and entrenchment theories 
emphasize the negative net effect of groups, depicting the pyramidal structures and opaque governance built for self-dealing and minority investor expropriation (Bertrand et al., 2002; Carney et al., 2017; Morck et al., 2005; Young et al., 2008).

Prior literature mainly analyzes the issue at the country level. Nenova (2003) argues that these benefits can be explained by the quality of general investor protection and minority rights in the case of a control transfer. In countries with high ownership concentration, the protection of minority shareholders is an issue where controlling shareholders might manipulate information and use corporate assets not to enhance profitability but rather to retain control over the firm (Al-Jaifi, 2017). Kim et al. (2007) review prior literature on the country's minority protection and ownership structure. Claessens et al. (2002) discuss whether a concentrated control structure of the whole corporate sector can lead to the suppression of minority rights and hold back institutional development.

Other literature looks at the issues at the firm level. Johnson et al. (2000a, b) provide examples of minority shareholder expropriation, and Bae et al. (2002) report that minority shareholders of Samsung Group affiliates were expropriated extensively in the late 1990s. Lemmon and Lins (2003) suggest that the ability to control the firm's assets is a necessary requirement for the expropriation of minority shareholders. Barucci and Falini (2005) show governance problems are greatest in firms with one large controlling shareholder. Ownership structure has also been investigated in multinational groups, regarding the effects on performance (Gu et al., 2018).

Arayssi and Jizi (2019) investigate the relationship between the ownership structure of companies and performance indicators (e.g. ROA) in the Middle East and North Africa (MENA) countries. They find that owner concentration is positively associated with ROA, suggesting that owners (families, holding companies, government) add value to the firm through their increased monitoring, investment and involvement in the board. Similar studies suggest the positive effect of specific governance factors on performance and firms' risks (Arayssi et al., 2016; Arayssi, 2015).

In continental Europe, dominant shareholders use pyramidal structures to acquire power (Claessens et al., 2000; Faccio and Lang, 2002; La Porta et al., 1999). Pyramids facilitate the accumulation of power because they allow for greater control of wealth with less investment by the owner (Morck et al.,2005) and the divergence between the dominant owner's voting and cash flow rights increases their incentives to expropriate minority shareholders (Bona-Sánchez et al., 2014).

We contribute to the literature by developing a measure of ownership-motivated income shifting. According to managerial opportunism theory, ownership structure creates incentives to shift income; income can, in fact, be shifted by the parent company from subsidiaries with a low percentage of control to subsidiaries with a high percentage of control to expropriate private benefits of control from minority shareholders. We use Huizinga and Laeven (2008)'s methodology in multinational firms and propose a model that considers profit shifting coming from different control percentages between subsidiaries in the same group. When minorities' interests account for a low percentage, this can be a proxy of a group similar to a nongroup company, where the manager and shareholder are free from bias coming from minority interest. Thus, we compare percentages of minority interests between different subsidiaries in a group in order to establish whether the income is shifted on the basis of different levels of minority interests.

H1. European multinational groups engage in ownership-motivated income shifting.

\subsection{Minority protection effect}

As reviewed by La Porta et al. (2000, 2008), prior literature shows that failure to establish strong investor protection carries high significant economic costs for firms individually and countries as a whole. The country index of investor protection has been widely used in the literature as a moderator effect of several relationships. Ownership is highly concentrated in 
weak investor protection countries (e.g. Claessens et al., 2000; Faccio and Lang, 2002; Lins, 2003; La Porta et al., 1999). Agency conflict between firm executives and controlling shareholders is minimal in weak investor protection countries, and the biggest agency conflict is between minority shareholders and controlling shareholders and their appointed executives (Chen et al., 2013). This literature shows that a wedge between the voting rights and cash flow rights is a key corporate governance factor that explains a wide variety of managerial behavior (e.g. Fan and Wong, 2002; Haw et al., 2004; Nenova, 2003). Chen et al. (2013) find that regulation on investor protection deters management from submitting value-decreasing corporate decisions. Moreover, the effect of the wedge in the voting and cash flow rights and the ensuing private benefits of control are found to be smaller in countries with stronger investor protection, consistent with the hypothesis that strong country-level investor protection limits management's ability to expropriate minority shareholders (Gong et al., 2013).

Doidge et al. (2007) suggest that weak country-level investor protection directly increases the costs that firms incur. Gong et al. (2013) find that management of firms located in weak investor protection countries is reluctant to disclose internal control deficiencies in order to protect its private control benefits.

Prior literature mainly views pyramids as a device through which controlling shareholders expropriate minorities (e.g. Bae et al., 2002; Baek et al., 2006; Bertrand et al., 2002; Claessens et al., 2002; Claessens and Fan, 2002). However, the dominant owner of a pyramid might not be motivated by opportunistic goals, as agency theory predicts, but might instead behave as a good steward of corporate resources. In line with this perspective, there is some literature that views pyramid structures as devices that allow the dominant owner to create a useful internal capital market (e.g. Cestone and Fumagalli, 2005; Cuervo, 2002; Williamson, 1985). Desai et al. (2004) find that such internal capital markets tend to be employed to obtain funds at a lower cost. The ability to shift income in pyramidal business groups provides outside investors with inter-corporate insurance in the case of financial distress (e.g. Bae et al., 2002; Bona-Sánchez et al., 2014; Friedman et al., 2003; Jian and Wong, 2010; Riyanto and Toolsema, 2008).

Given prior literature, we expect that in countries with a higher level of minority protection, ownership-motivated income shifting is moderated by the benefits brought by regulation.

H2. Ownership-motivated income shifting effect is moderated by country minorities protection

\subsection{Tax or ownership motivated income shifting}

Tax-motivated income shifting can be a legitimate activity that creates advantages for all group members, or it can be a fraudulent activity, which gives advantages to only certain categories.

The model to measure tax-motivated income shifting was developed in groups and, specifically, in multinational groups. Seminal research in the 1990s already investigated income shifting with early-stage methods (Collins et al., 1998; Jacob, 1996; Klassen et al., 1993). The model which combined profitability and tax incentive to measure income shifting was developed by Huizinga and Laeven (2008). They propose a model which considers tax differences between affiliates in different host countries, as well as profit shifting, arising from international tax differences between affiliates and parent companies. They find that profits of a subsidiary of a multinational group are negatively related to a weighted average (called C) of international tax rate differences between the subsidiary's country and all other countries where the multinational is active. Using a framework that allows for-profit shifting between foreign subsidiaries, as well as between any foreign subsidiary and the parent firm, they find significant evidence of tax-motivated profit shifting between subsidiaries and between parents and subsidiaries.

Several studies refer to this model (Dharmapala and Riedel, 2013; Klassen and Laplante, 2012; De Simone et al., 2017). De Simone et al. (2017) find that multinational groups follow a 
shift-to-loss strategy and shift income from profitable affiliates to loss affiliates, in spite of considerable costs associated with this strategy. Klassen and Laplante (2012) provide support for policymakers' concerns that firms engage in tax-motivated income shifting, and estimate that their sample shifts approximately $\$ 10$ billion or more income out of the United States.

Income shifting in European groups

Based on this measure of tax-motivated income shifting, researchers investigate the relation between income tax-motivated shifting and firm-specific determinants and their variation across major industries (Beer and Loeprick, 2015), in addition to many other analyzes (Beuselinck et al., 2015; Brajcich et al., 2016; Dyreng and Markle, 2016; Hopland et al., 2018; Markle, 2016; De Simone, 2016).

Chen et al. (2018) argue that tax-motivated income shifting increases the complexity of the firms' operations and decreases the transparency of accounting information. From another point of view, McGuire et al. (2018) show that with good quality of internal information environment, tax-motivated income shifting increases, suggesting that this quality enables managers to identify and take advantage of income shifting opportunities.

The relation between tax and ownership has been analyzed only with regard to tax avoidance. The literature analyzes whether a specific form of ownership influences tax avoidance, using consolidated financial data. Our aim, on the other hand, is to analyze whether ownership prevails on the effect of tax motivation into income-shifting choices, looking at the separate financial statements of the subsidiaries in a multinational group.

Since tax avoidance is a risky activity that can impose high significant costs (e.g. Desai and Dharmapala, 2006; Hanlon and Heitzman, 2010; Rego and Wilson, 2012), firms majority-owned by the firm's managers are less willing to pursue tax avoidance (Badertscher et al., 2013). Nongovernment-controlled firms pursue a more aggressive tax strategy (Chan et al., 2013). When the difference between voting rights and cash flow rights increases, the extent of tax avoidance decreases (Mcguire and Wilson, 2014). Tax avoidance is negatively associated with the cost of debt, and this negative relationship becomes stronger when the level of institutional ownership is high, and even stronger when the shareholder rights of institutional investors are strengthened (Lim, 2011). Positive shocks to institutional ownership lead to significant decreases in effective tax rates and greater use of international tax planning using tax haven subsidiaries (Bird and Karolyi, 2017; Khan et al., 2017).

Richardson et al. (2016) analyze the differences between cash flow and voting rights in China. At a lower level, increased ownership concentration is positively associated with tax avoidance due to the entrenchment effect. However, beyond the minimum level necessary for effective control, concentrated ownership is negatively associated with tax avoidance because of the alignment effect. When the controlling owner is entrenched through his voting power (the entrenchment argument), there is a greater likelihood of shareholder wealth expropriation through tax avoidance. Any further increase in the controlling shareholder's ownership share (the alignment argument) can alleviate the problem of entrenchment and reduce the related agency costs by aligning the interests of the controlling owners with those of minority shareholders (Fan and Wong, 2002; Shleifer and Vishny, 1986). Gomes (2000) claims that a high ownership concentration is a signal of a controlling owner's commitment to building a reputation for not expropriating minority shareholders' wealth. In other words, when the ownership concentration increases more than the minimum level necessary to have effective control, the opportunistic behavior by the controlling owners and their incentive to engage in tax avoidance decrease (alignment effect).

Rather than examining the effect of ownership on taxation issues, our study asks whether ownership motivation to shift income holds in cases where there is also motivation to shift income for taxation purposes. The tax-motivated income shifting effect could be the only relevant if the tax planning strategy prevails on other strategies. In concentrated groups, the problem of minorities is less present, so the incentive to expropriate minorities' interests is also lower. In European multination groups, the family concentrated model prevails, so the 
tax-motivated income shifting effect could be the only relevant effect. Moreover, if minorities hold power, ownership-motivated income shifting could be difficult to implement.

On the other hand, it may be the case that the ownership-motivated income shifting effect is present together with the tax-motivated effect. Given measures taken to harmonize tax rates across Europe, tax-motivated income shifting may have lost its importance, and ownership-motivated income shifting may have become the dominant effect. In our third hypothesis, we expect that in a model that includes both tax-motivated and ownershipmotivated income shifting, the second effect is statistically significant.

H3. European multinational groups engage in ownership-motivated income shifting even after controlling for the engagement in tax-motivated income shifting effect.

\section{Model}

Huizinga and Laeven (2008) apply the Cobb-Douglas production function to estimate profits associated with the economic activity in a jurisdiction and propose the idea that an entity reports profits that are composed of the real profit, as well as profits of income shifting. They also consider that real profit is unobservable and so must be estimated. Following Hines and Rice (1994); Huizinga and Laeven (2008) assume a Cobb-Douglas production function, and the true profit is equal to output minus the cost of wages. By using the logarithms of both sides of the equation for real profit and substituting into their equation for reported profit, they arrive at an estimation model that expresses reported income as a function of capital inputs and labor, a general productivity component, and a measure of tax incentive and opportunity. This model is commonly used in income shifting literature. To test our hypothesis we adapt the Huizinga and Laeven (2008) model using the following equations:

$$
\begin{aligned}
\ln (\mathrm{PBT})= & \beta \text { Ownership subsidiaries }+\beta \ln (\text { Tangible Assets })+\beta \ln (\text { Comp Exp }) \\
& +\beta \ln (\mathrm{GDP})+\text { year fixed effects }+e \\
\ln (\mathrm{PBT})= & \beta \text { Ownership subsidiaries }+\beta \text { Ownership subsidiaries*Minorities protection } \\
& +\beta \ln (\text { Tangible Assets })+\beta \ln (\text { Comp Exp })+\beta \ln (\mathrm{GDP}) \\
& + \text { year fixed effects }+e
\end{aligned}
$$

$$
\begin{aligned}
\ln (\mathrm{PBT})= & \beta C \text { tax foreign subsidiaries }+\beta \text { Ownership subsidiaries } \\
& +\beta \ln (\text { Tangible Assets })+\beta \ln (\text { Comp Exp })+\beta \ln (\mathrm{GDP}) \\
& + \text { year fixed effects }+e
\end{aligned}
$$

Our dependent variable is the natural logarithm of profit before tax of the subsidiary investigated, which in our sample is always positive, following Markle (2016). We use the traditional control variables, following Huizinga and Laeven (2008). Our proxy for capital is tangible fixed assets, and for labor, it is compensation expense. Consistent with prior studies (Markle, 2016), we use GDP as the proxy for general productivity.

We derive that Ctax foreign subsidiaries (in Eqn 3) represents tax incentive and opportunities that are computed following the literature (Beuselinck et al., 2015; Markle, 2016; De Simone, 2016). The variable $C$ tax foreign subsidiaries is a composite tax variable, which summarizes all information about profit shifting incentives (tax rates) and about profit shifting opportunities (firm's revenues). A positive value of $C$ tax foreign subsidiaries implies that the multinational firm optimally shifts profits out of the country. See Appendix for variables definition. We expect $\beta$ of $C$ tax foreign subsidiaries to be negative if a tax incentive to shift income between subsidiaries exists. A negative coefficient is interpreted as tax-motivated income shifting between subsidiaries. 
Eqn 1 shows ownership-motivated income shifting (H1). Unlike the coefficient of $C$ tax foreign subsidiaries, which is expected to be negative, we expect $\beta$ of Ownership subsidiaries to be positive if an ownership incentive and opportunities to shift income among the subsidiaries exist. A positive coefficient is interpreted as ownership-motivated income shifting among the subsidiaries. In fact, a high statutory tax rate pushes out incomes $(\pi)$, and a high percentage of control attracts income $(\gamma)$.

Eqn 2 includes the interaction term with minority protection and aims to test the effect of minority protection (H2). Appendix shows the details of this index.

Eqn 3 includes both tax-motivated and the ownership-motivated income shifting in the same model. We aim to test whether $\beta$ Ownership subsidiaries are statistically significant even after controlling for $\beta C$ tax subsidiaries (H3).

In other words, our method analyzes the main explanatory variable Ownership subsidiaries in Model 1. In Model 2, the coefficient of the test is the $\beta$ of the interaction Ownership subsidiaries*Minorities protection.

\section{Sample}

We investigate European multinational groups, using data from Bureau Van Dijk's database. Table 1 outlines the sample selection. In particular, we exclude banks and insurance groups. Since consolidated losses create incentives to change the income-shifting strategy, we further require that the consolidated group be profitable, reporting a return on sales of at least $3 \%$. We use the ownership data to match European firms with their domestic $\mathrm{C}$ tax foreign subsidiaries and subsidiaries located in other European firms. A firm is defined to be a subsidiary if at least $50 \%$ of the shares are owned by another single firm. As we are interested in international profit shifting, we restrict our sample to multinational firms that have at least one foreign subsidiary. The initial sample includes 17,949 parent firms.

We then download data for each subsidiary of these 17,949 parent firms. We exclude bank and insurance subsidiaries and subsidiaries owned at less than $50 \%$. We require reporting firms to have basic accounting information over the years, i.e., data on tangible assets, intangible assets, total assets, earnings before interest and tax, taxation, sales and independent variables, such as compensation expense, gross domestic product. We also exclude affiliates under joint control. This gives a sample of 33,012 subsidiary firms.

We use unconsolidated company information over the period 2009 to 2015 for all tests. These criteria yield a beginning sample of 199,863 subsidiaries-year observations. We select

\begin{tabular}{lr}
\hline Description & \multicolumn{1}{c}{$N$} \\
\hline $\begin{array}{l}\text { French, German, Italian, Spanish, United Kingdom nonfinancial firms (excluding US SIC codes 6) } \\
\text { in Bureau van Dijk's Amadeus database with group consolidated earnings before taxes negative }\end{array}$ & $2,154,846$ \\
and return on sales less than 3\% & \\
Less: Firms with no foreign affiliate or with foreign affiliate owned less than 50\% & $-2,136,897$ \\
Parent firms & 17,949 \\
Nonbanks and noninsurance (US SIC codes 6) UE subsidiaries owned more or equal than 50\% & 103,612 \\
for these 17,949 parent firms & $-70,107$ \\
Less: subsidiaries firms with missing tangible assets, intangible assets, total assets, EBIT, & -493 \\
taxation and sales and other independent variables & 33,012 \\
Less: Affiliates at joint control & 199,863 \\
Subsidiaries & $-195,834$ \\
Subsidiaries -years in the period 2009 to 2015 (unbalanced sample) & $-2,339$ \\
Less: Observations with missing data for ownership and with negative net income & 1,690 \\
Less: Observations with a pair of subsidiaries in the same country & Final number of observations
\end{tabular}

Table 1. Sample selection 
$\mathrm{MD}$

58,12

2628

only profitable firms to implement the Huizinga and Laeven (2008) model. We finally delete observations with missing data for the variable of interest (i.e. no ownership data and no value for the variable of ownership-motivated income shifting). Then, to test income shifting between subsidiaries, we delete the observations where the pair subsidiaries are in the same country (final observations of 1,965).

We investigate groups with parent firms that have headquarters in the five largest countries in the European Monetary Union (EMU) on the basis of gross domestic product (classification of International Monetary Fund-IMF): Germany, United Kingdom, French, Italy and Spain. Subsidiaries are located in other European countries. Table 2 shows the country distribution of the subsidiary-year observations. Several subsidiaries are local and located in the same country as the parentfirm, but they can still shift income with other subsidiaries in the same group in other countries, so they are excluded only from the analysis of income shifting between parent firm and subsidiaries.

The population consists of listed companies, organized in a group and preparing consolidated financial reporting, with at least one subsidiary abroad, resulting in 1,690

\begin{tabular}{|c|c|c|c|c|c|c|}
\hline Country & Germany & Spain & France & United Kingdom & Italy & Total \\
\hline \multicolumn{7}{|c|}{$\begin{array}{l}\text { Panel A: Number of subsidiary firms-year of French, German, Italian, Spanish, United Kingdom parent firms } \\
\text { that are located in the following countries }\end{array}$} \\
\hline Austria & 4 & 0 & 0 & 0 & 0 & 4 \\
\hline Belgium & 69 & 27 & 203 & 49 & 26 & 374 \\
\hline Germany & 0 & 24 & 87 & 23 & 60 & 194 \\
\hline Spain & 97 & 0 & 189 & 35 & 179 & 500 \\
\hline Finland & 15 & 0 & 6 & 1 & 2 & 24 \\
\hline France & 1 & 0 & 0 & 2 & 0 & 3 \\
\hline United Kingdom & 0 & 0 & 3 & 0 & 0 & 3 \\
\hline Greece & 0 & 0 & 0 & 0 & 1 & 1 \\
\hline Italy & 34 & 26 & 52 & 16 & 0 & 128 \\
\hline Lithuania & 0 & 0 & 1 & 0 & 0 & 1 \\
\hline Malta & 0 & 0 & 0 & 1 & 0 & 1 \\
\hline Netherland & 3 & 0 & 12 & 1 & 3 & 19 \\
\hline Poland & 0 & 0 & 3 & 0 & 3 & 6 \\
\hline Portugal & 37 & 232 & 103 & 18 & 38 & 428 \\
\hline Sweden & 4 & 0 & 0 & 0 & 0 & 4 \\
\hline Total & 264 & 309 & 659 & 146 & 312 & 1,690 \\
\hline Country & 2009 & 2010 & 2011 & 2013 & 2014 & 2015 \\
\hline \multicolumn{7}{|c|}{ Panel B: Sample composition of protection of minorities by country-year (scale 1-7) } \\
\hline AUT & & & 5.085 & 4.994 & 4.788 & 4.948 \\
\hline BEL & 4.901 & 5.000 & 4.933 & 4.788 & 4.929 & 5.049 \\
\hline DEU & 5.230 & 4.843 & 4.936 & 4.794 & 4.678 & 4.714 \\
\hline ESP & 4.148 & 4.300 & 4.213 & 3.981 & 3.745 & 3.718 \\
\hline FIN & & & & 6.209 & 6.173 & 6.065 \\
\hline FRA & 4.661 & 4.773 & & & 4.358 & \\
\hline GBR & & & 5.210 & 5.203 & 5.270 & \\
\hline GRC & & & & & & 4.084 \\
\hline ITA & 3.388 & & 3.526 & 3.255 & 3.262 & 3.476 \\
\hline LTU & & & & 3.872 & & \\
\hline MLT & & & & 5.158 & & \\
\hline NLD & 5.112 & 5.185 & 5.359 & 5.356 & 5.409 & 5.332 \\
\hline POL & & & & 3.869 & 4.000 & 4.147 \\
\hline PRT & 4.547 & 4.477 & 4.313 & 4.240 & 4.448 & 4.083 \\
\hline SWE & & 5.954 & & 5.622 & 5.488 & 5.427 \\
\hline
\end{tabular}

Table 2.

Sample composition and measures by country 
observations, with an average of 338 observations for each of the 5 countries, and an average of 48 firms per year.

\section{Descriptive statistics and correlation matrix}

Table 3 shows descriptive statistics. Given our sample selection method, the dependent variable always shows a positive profit for the subsidiaries investigated. The mean profitability (about 4,5 million euro) is different from the median (about 1 million euro), given that the sample includes listed and unlisted firms owned at least $50 \%$. The use of logarithm reduces this problem and makes it possible to perform the analysis.

The mean of $\gamma_{i}$ the percentage of control (voting rights) of subsidiary $i$ is equal to $93.3 \%$ and its median is $100 \%$. This value has a minimum of $50 \%$ (untabulated), given that we select only the controlled subsidiaries based on the strongest definition of control. We have a very high ownership concentration sample. This is a characteristic of a European sample, unlike, for example, the setting of China, where ownership is more widely dispersed (see Richardson et al., 2016). The variable Ownership subsidiaries have a mean of 0.011 .

The mean of $\pi_{i}$ statutory tax rate of subsidiary $i$ is $28.9 \%$, while the mean of $\pi_{p}$ statutory tax rate of parent $p$ is $30.8 \%$. These percentages represent the average tax rate on income in the countries where our sample subsidiary and parent companies are located. The mean and the median value of $C$ tax foreign subsidiaries and $C$ tax parent companies are close to zero, since it is a weighted average of bilateral tax differences within a corporate group (Markle, 2016).

The descriptive statistics of the control variables show the mean value of tangible assets and compensation expenses. Table 4 shows the correlation matrix appears to have no multicollinearity issues. The highest correlation between independent variables is between compensation expense and tangible assets (0.548). The mean VIF is 1.69 and shows no multicollinearity issues.

\section{Results and discussion}

Table 5 Model 1 shows the results for Ownership subsidiaries for H1, while Model 2 tests H2 with the interaction with investor protection.

\begin{tabular}{lccccc}
\hline & Mean & Std. Dev. & 25th perc. & Median & 75th perc. \\
\hline Dependent variables & & & & & \\
PBT & 4,484 & 11,901 & 356 & 989 & 3,221 \\
$\ln (\mathrm{PBT})$ & 6.977 & 1.713 & 5.875 & 6.897 & 8.077 \\
& & & & & \\
Independent variables & & & & \\
$\gamma_{i}$ percentage of control (voting rights) $i$ & 0.933 & 0.139 & 0.960 & 1.000 & 1.000 \\
Ownership subsidiaries & 0.011 & 0.137 & -0.027 & 0.000 & 0.015 \\
Minorities protection index & 4.376 & 0.561 & 3.981 & 4.313 & 4.843 \\
$\pi_{i}$ statutory tax rate $i$ & 0.289 & 0.039 & 0.250 & 0.300 & 0.314 \\
C tax subsidiaries & 0.051 & 0.810 & -0.040 & 0.002 & 0.241 \\
$\pi_{p}$ statutory tax rate $p$ & 0.308 & 0.030 & 0.297 & 0.314 & 0.333 \\
C tax parent & -0.036 & 0.053 & -0.067 & -0.047 & 0.009 \\
TangibleAssets & 15,600 & 84,992 & 157 & 844 & 4212 \\
$\ln$ (TangibleAssets) & 6.745 & 2.349 & 5.056 & 6.738 & 8.346 \\
CompExp & 8,888 & 26,088 & 1,013 & 2,503 & 6,670 \\
$\ln$ (CompExp) & 7.894 & 1.476 & 6.921 & 7.825 & 8.805 \\
GDP & 25,383 & 6,972 & 17,000 & 23,200 & 33,600 \\
$\ln$ (GDP) & 10.102 & 0.286 & 9.741 & 10.052 & 10.422
\end{tabular}

Note(s): Refer to Appendix for variable definitions

in European

groups \\ 2629}


$\mathrm{MD}$

58,12

\section{0}

Table 4.

Pearson correlation matrix
Model 1 yields the expected positive relation between Ownership subsidiaries and profit before tax (H1). A positive coefficient is interpreted as ownership-motivated income shifting. The results on the labor, capital, and productivity proxies and the tax variable are similar to those estimated using European data (Huizinga and Laeven, 2008) and international data (Markle, 2016). Our finding confirms the negative net effect generated by the groups, where the pyramidal structures and opaque governance mechanisms built for self-dealing and minority investor expropriation (Bertrand et al., 2002; Carney et al., 2017; Morck et al., 2005; Young et al., 2008). This ownership-motivated income shifting is an example of minority expropriation. In fact, when minority interests represent a low percentage, this can be a proxy of a group similar to nongroup company, where the manager and shareholder are free from bias coming from minority interest. Comparing the percentage of minority interests between different subsidiaries in a group, we find that income appears to be shifted according to the different levels of minority interests. Most of the prior literature focuses on tax avoidance as the reason for income shifting in multinational groups. Our results make a contribution to the literature as they reveal that intragroup transactions may also aim to expropriate minorities. We suggest using models developed by Huizinga and Laeven (2008) and Markle (2016) to test the expropriation of minority interests.

The findings of Model 2 show the effect of minority protection by country (H2). In other words, the ownership-motivated income shifting effect is affected by the level of minority protection. Our findings confirm the strand of literature according to which failure to protect

\begin{tabular}{|c|c|c|c|c|c|c|c|c|}
\hline & & 1 & 2 & 3 & 4 & 5 & 6 & 7 \\
\hline 1 & $\ln (\mathrm{PBT})$ & 1.000 & & & & & & \\
\hline 2 & Ownership subsidiaries & 0.037 & 1.000 & & & & & \\
\hline 3 & Minorities protection index & 0.060 & 0.033 & 1.000 & & & & \\
\hline 4 & $C$ tax foreign subsidiaries & -0.041 & 0.411 & 0.053 & 1.000 & & & \\
\hline 5 & $\ln$ (TangibleAssets) & 0.519 & 0.030 & -0.001 & 0.040 & 1.000 & & \\
\hline 6 & $\ln ($ CompExp) & 0.655 & 0.032 & 0.029 & -0.027 & 0.548 & 1.000 & \\
\hline 7 & $\ln (\mathrm{GDP})$ & 0.195 & 0.024 & 0.501 & -0.017 & 0.025 & 0.240 & 1.000 \\
\hline
\end{tabular}

\begin{tabular}{|c|c|c|c|c|c|}
\hline \multirow[b]{2}{*}{ Dependent variable $\ln (\mathrm{PBT})$} & \multirow[b]{2}{*}{ Exp. Sign } & \multicolumn{2}{|c|}{$\begin{array}{c}\text { Ownership- } \\
\text { motivated income } \\
\text { shifting between } \\
\text { pairs of } \\
\text { subsidiaries } \\
\text { Model 1 }\end{array}$} & \multicolumn{2}{|c|}{$\begin{array}{l}\text { Moderation of } \\
\text { minority protection } \\
\text { Model } 2\end{array}$} \\
\hline & & Estimate & $p$-value & Estimate & $p$-value \\
\hline Ownership subsidiaries & + & 0.450 & 0.017 & 2.609 & 0.058 \\
\hline Ownership subsidiaries * protection of minorities & - & & & -0.489 & 0.095 \\
\hline $\ln$ (TangibleAssets) & + & 0.157 & $<0.001$ & 0.157 & $<0.001$ \\
\hline $\ln ($ CompExp) & + & 0.571 & $<0.001$ & 0.571 & $<0.001$ \\
\hline $\ln (\mathrm{GDP})$ & ? & 0.531 & $<0.001$ & 0.538 & $<0.001$ \\
\hline Constant & & -3.915 & $<0.001$ & - & \\
\hline Year and parent firm fixed effects & & included & & included & \\
\hline Adj. $R^{2}$ & & 0.472 & & 0.472 & \\
\hline Number of observation & & 1,690 & & 1,690 & \\
\hline
\end{tabular}

Table 5.

Multivariate analysis of ownershipmotivated income shifting 


\begin{tabular}{|c|c|c|c|c|}
\hline \multirow[b]{2}{*}{ Dependent variable $\ln (\mathrm{PBT})$} & \multirow[b]{2}{*}{ Exp. Sign. } & \multicolumn{2}{|c|}{$\begin{array}{l}\text { Ownership-motivated and tax- } \\
\text { motivated income shifting } \\
\text { between pairs of subsidiaries } \\
\text { Model } 3\end{array}$} & \multirow[t]{2}{*}{$\begin{array}{r}\text { Income shifting } \\
\text { in European } \\
\text { groups }\end{array}$} \\
\hline & & Estimate & $p$-value & \\
\hline$C$ tax foreign subsidiaries & - & -0.055 & \multirow{9}{*}{$\begin{array}{r}0.170 \\
0.010 \\
<0.001 \\
<0.001 \\
<0.001 \\
0.001\end{array}$} & \\
\hline Ownership subsidiaries & + & 0.536 & & 2631 \\
\hline $\ln$ (TangibleAssets) & + & 0.157 & & \\
\hline $\ln ($ CompExp) & + & 0.570 & & \\
\hline $\ln (\mathrm{GDP})$ & $?$ & 0.527 & & \\
\hline Constant & & -3.869 & & \\
\hline Year and parent firm fixed effects & & included & & Multivariate analysis \\
\hline $\begin{array}{l}\text { Adj. } R^{2} \\
\text { Number of observation }\end{array}$ & & $\begin{array}{l}0.486 \\
1,690\end{array}$ & & \\
\hline Note(s): Coefficient $p$-values are ol & er to Append & definitions & & \\
\hline
\end{tabular}

investors carries high significant economic costs for firms individually and countries as a whole (La Porta et al., 2000, 2008). Ownership-motivated income shifting, as an example of minority shareholder expropriation, is clearly reduced by high standards of minority protection. A robust legal system reduces the use of pyramidal groups for self-dealing and minority investor expropriation. The regulation on investor protection deters management from submitting value-decreasing decisions for minorities. Our results are also consistent with the assumption that strong country-level investor protection limits management's ability to expropriate minority shareholders (Gong et al., 2013). Ownership-motivated income shifting performed by multinational groups can lead to minority expropriation, and government strategy to limit this behavior is important in protecting minorities. It is not easy to measure and evaluate the effectiveness of state regulations protecting minorities, but the World Economic Forum index is an important signal, and it is a useful starting point for governments in legislating in national contexts on the legal protection of minorities.

Table 6 includes Model 3, which develops answers to H3. Probably due to the harmonization of tax rates across Europe and the group planning strategy, tax-motivated income shifting losses its importance and ownership-motivated income shifting becomes the dominant effect. In fact, where tax-motivated and ownership-motivated income shifting are included in the same model, ownership motivations prevail. Our results show that after controlling for $\beta C$ tax subsidiaries, $\beta$ Ownership subsidiaries remain statistically significant ( $p$-value equal to 0.010). It appears that multinational groups pursue tax-avoidance and expropriation of minorities precisely through income shifting and intragroup transactions. Ownership-motivated income shifting trumps intragroup transactions, probably because gaps in regulations permit the use of pyramidal structures and opaque governance for selfdealing and minority investors' expropriation.

\section{Robustness}

To assess the robustness of our results, we also ran some sensitivity tests. First, we performed a robustness check controlling for country fixed effect, and second, we repeated our analysis in a subsample with a high level of tax motivation (subsample with a tax rate above the median). In both cases, our main result was confirmed, and the overall interpretation of the results does not vary. Table 7 shows that results are consistent with those of the baseline regressions. They are robust controlling for both the fixed effect of the country of the subsidiaries and considering the subsample of countries where the tax rate is high, above the median. 
$\mathrm{MD}$

58,12

\begin{tabular}{|c|c|c|c|c|c|}
\hline \multirow[b]{2}{*}{ Dependent variable $\ln (\mathrm{PBT})$} & \multirow[b]{2}{*}{ Exp. Sign } & \multicolumn{2}{|c|}{$\begin{array}{l}\text { Country subsidiary } \\
\text { firms fixed effect }\end{array}$} & \multicolumn{2}{|c|}{$\begin{array}{c}\pi_{i} \text { statutory tax rate } \\
i>0.300 \text { Countries of } \\
\text { the subsidiaries with } \\
\text { tax rate above the } \\
\text { median }\end{array}$} \\
\hline & & Estimate & $p$-value & Estimate & $p$-value \\
\hline wnership subsidiaries & + & 0.562 & 0.020 & 0.211 & 0.027 \\
\hline n(TangibleAssets) & + & 0.116 & $<0.001$ & 0.151 & $<0.001$ \\
\hline (CompExp) & + & 0.644 & 0.290 & 0.559 & $<0.001$ \\
\hline n(GDP) & ? & -0.122 & $<0.001$ & 1.342 & 0.213 \\
\hline rear and parent firm fixed effects & & included & & included & \\
\hline country subsidiary firms fixed effect & & included & & - & \\
\hline dj. $R^{2}$ & & 0.481 & & 0.477 & \\
\hline Jumber of observation & & 1,690 & & 861 & \\
\hline
\end{tabular}

Table 7.

Robustness

Note(s): Coefficient $p$-values are one-tailed. Refer to Appendix for variable definitions

\section{Conclusion}

This study focuses on the incentives that European multinational groups have to shift income between subsidiaries and the parent company through intragroup transactions. Prior literature analyzes tax-motivated income shifting extensively, but other incentives to shift income, as for example, the ownership structure and the weight of minority interest, have been relatively little discussed. Income shifting is, however, a widespread phenomenon, which characterizes most multinational groups.

Using a sample of European companies, we investigate the existence of an ownershipmotivated income shifting and a possible moderation effect in countries with high minority protection. We further explore whether ownership-motivated income shifting is statistically significant even if it is in competition with the tax-motivated income shifting.

Results show that European multinational groups performing income shifting are motivated by the incentive to expropriate minority interests. However, our findings show that in countries with a high level of regulation, minority protection moderates the phenomenon. Results also reveal that after controlling for tax-motivated income shifting, ownershipmotivated income shifting is still significant.

This study opens a new avenue of research into income-shifting decisions. Our results suggest, for example, that managers take into account ownership structure and the level of minority interests in shifting income. From the parent company perspective, tax motivation and minority expropriation have similar effects: they both increase the net income for the parent company shareholders. It appears that income is often shifted from subsidiaries with a low level of voting rights to subsidiaries with a high level of voting rights.

The contribution made to the literature can be summarized as follows. First, the strategy of income shifting has different aims: the expropriation of minorities, in addition to the more widely recognized aim of tax avoidance. Previous literature, in fact, focuses mostly on tax avoidance as a reason for income shifting in multinational groups, and this study adds knowledge by showing that there is often the additional aim of expropriating minorities through intragroup transactions. Second, the prevalence of one effect over the other has not hitherto been recognized, so it has not been possible to identify strategies for preventing income shifting. We find that in a model, including both tax-avoidance and minority expropriation reasons, minority expropriation is significant. Our contribution is thus related to the statistical significance of minority expropriation after controlling for the other motivation.

Several countries have already adopted legislation that requires, for example, a level of minority representation on the Board of Directors and/or in the Audit Committee, although 
this is usually mandatory only for listed companies. Our findings should be of use for the future drafting of taxation policy and legislation on corporate governance and legal protection. They also have implications for investors and society. For governments, the findings on the effect of minorities' protection may be the starting point to promote and enact regulation focusing on minorities. Taking a long term view, in fact, it is likely that countries with robust legal protection measures in place will be more attractive for investments. Stakeholder protection is a key issue for regulations and is particularly significant in guaranteeing minorities' interests. In other words, the prevention of minority interest expropriation entails sound legal protection. This research is also of interest to companies and investors which place resources and take investment decisions, as it enables them to take better informed decisions and evaluate the best solutions and contexts for investments.

Although the study looks at a wide range of subsidiaries, a limitation may be that it examines only firms having parent companies in five European countries. Further research would overcome this limitation and extend the literature, also taking into account other income-shifting contextual variables, which describe the scenario in more detail.

\section{References}

Al-Jaifi, H.A. (2017), "Ownership concentration, earnings management and stock market liquidity: evidence from Malaysia”, Corporate Governance (Bingley), Vol. 17 No. 3, pp. 490-510.

Almeida, H.V. and Wolfenzon, D. (2006), "A theory of pyramidal ownership and family business groups", The Journal of Finance, Vol. 61 No. 6, pp. 2637-2680.

Arayssi, M. (2015), “The effect of private investments on banks' capital requirements”, The European Journal of Finance, Vol. 22 No. 15, pp. 1580-1595.

Arayssi, M. and Jizi, M. (2019), "Does corporate governance spillover firm performance? A study of valuation of MENA companies", Social Responsibility Journal, Vol. 15 No. 5, pp. 597-620.

Arayssi, M., Dah, M. and Jizi, M. (2016), "Women on boards, sustainability reporting and firm performance", Sustainability Accounting, Management and Policy Journal, Vol. 7 No. 3, pp. 376-401.

Badertscher, B.A., Katz, S.P. and Rego, S.O. (2013), "The separation of ownership and control and corporate tax avoidance", Journal of Accounting and Economics, Elsevier, Vol. 56, pp. 228-250.

Bae, K.H., Kang, J.K. and Kim, J.M. (2002), "Tunneling or value-added: evidence from mergers by Korean business groups”, Journal of Finance, Vol. 57, pp. 2695-2740.

Baek, J.S., Kang, J.K. and Lee, I. (2006), "Business groups and tunnel- ing: evidence from private securities offerings by Korean Chaebols", Journal of Finance, Vol. 61, pp. 2415-2449.

Barclay, M. and Clifford, H. (1989), "Private benefits from control of public corpora- tions", Journal of Financial Economics, Vol. 25, pp. 371-395.

Barucci, E. and Falini, J. (2005), "Determinants of corporate governance in the Italian financial market”, Economic Notes, Vol. 34, pp. 371-405.

Beer, S. and Loeprick, J. (2015), "Profit shifting: drivers of transfer (mis) pricing and the potential of countermeasures", International Tax and Public Finance, Vol. 22, pp. 426-451.

Bertrand, M., Mehta, P. and Mullainathan, S. (2002), "Ferreting out tunneling: an application to Indian business groups", The Quarterly Journal of Economics, Vol. 117 No. 1, pp. 121-148.

Beuselinck, C., Deloof, M. and Vanstraelen, A. (2015), "Cross-jurisdictional income shifting and tax enforcement: evidence from public versus private multinationals", Review of Accounting Studies, Vol. 20, pp. 710-746.

Bird, A. and Karolyi, S.A. (2017), "Governance and taxes: evidence from regression discontinuity", The Accounting Review, Vol. 92 No. 1, pp. 29-50. 
$\mathrm{MD}$

58,12

2634

Bona-Sánchez, C., Pérez-Alemán, J. and Santana-Martín, D.J. (2014), "Politically connected firms and earnings informativeness in the controlling versus minority shareholders context: European evidence", Corporate Governance: An International Review, Vol. 22 No. 4, pp. 330-346.

Brajcich, A.M., Friesner, D.L. and Schibik, T.J. (2016), "Do US pharmaceutical companies strategically shift income to international affiliates?”, Multinational Business Review, Vol. 24 No. 1, pp. 8-24.

Cainelli, G. and Iacobucci, D. (2011), "Business groups and the boundaries of the firm", Management Decision, Vol. 49 No. 9, pp. 1549-1573.

Carney, M., Van Essen, M., Estrin, S. and Shapiro, D. (2017), "Business group prevalence and impact across countries and over time”, Multinational Business Review, Vol. 25 No. 1, pp. 52-76.

Cestone, G. and Fumagalli, C. (2005), "The strategic impact of resource flexibility in business groups. RAND”, Journal of Economics, Vol. 36, pp. 193-214.

Chan, K.H., Mo, P.L.L. and Zhou, A.Y. (2013), "Government ownership , corporate governance and tax aggressiveness: evidence from China”, Accounting and Finance, Vol. 53, pp. 1029-1051.

Chen, I.F. and Chang, S.C. (2016), "The intra business group effects of alliance network extensions", Management Decision, Vol. 54 No. 6, pp. 1420-1442.

Chen, Z., Ke, B. and Yang, Z. (2013), "Minority shareholders' control rights and the quality of corporate decisions in weak investor protection countries: a natural experiment from China", The Accounting Review, Vol. 88 No. 4, pp. 1211-1238.

Chen, C.W., Hepfer, B.F., Quinn, P.J. and Wilson, R.J. (2018), "The effect of tax-motivated income shifting on information asymmetry", Review of Accounting Studies, Review of Accounting Studies, Vol. 23 No. 3, pp. 958-1004.

Claessens, S. and Fan, J.P.H. (2002), “Corporate governance in Asia: a survey”, International Review of Finance, Vol. 3, pp. 71-104.

Claessens, S., Djankov, S. and Lang, L.H. (2000), "The separation of ownership and control in East Asian corporations", Journal of Financial Economics, Vol. 58 Nos 1-2, pp. 81-112.

Claessens, S., Djankov, S., Fan, J.P.H., Lang, L.H.P., Journal, T. and Dec, N. (2002), "Disentangling the incentive and entrenchment effects of large shareholdings disentangling the incentive and entrenchment effects of large shareholdings", The Journal of Finance, Vol. 57 No. 6, pp. 2741-2771.

Collins, J., Kemsley, D. and Lang, M. (1998), "Cross-Jurisdictional income shifting and earnings valuation", Journal of Accounting Research, Vol. 36 No. 2, pp. 209-229.

Cuervo, A. (2002), "Corporate governance mechanisms: a plea for less code of good governance and more market control”, Corporate Governance: An International Review, Vol. 10, pp. 84-93.

De Simone, L. (2016), "Does a common set of accounting standards affect tax-motivated income shifting for multinational firms?”, Journal of Accounting and Economics, Elsevier, Vol. 61 No. 1, pp. 145-165.

De Simone, L., Klassen, K.J. and Seidman, J.K. (2017), "Unprofitable affiliates and income shifting behavior", The Accounting Review, Vol. 92 No. 3, pp. 113-136.

Desai, M. and Dharmapala, D. (2006), "Corporate tax avoidance and high-powered incentives”, Journal of Financial Economics, Vol. 79, pp. 145-179.

Desai, M.A., Foley, C.F. and Hines, J.R. (2004), “A multinational perspective on capital structure choice and internal capital markets", Journal of Finance, Vol. 59, pp. 2451-2487.

Dharmapala, D. and Riedel, N. (2013), "Earnings shocks and tax-motivated income-shifting: evidence from European multinationals", Journal of Public Economics, Vol. 97, pp. 95-107.

Doidge, C., Karolyi, G.A. and Stulz, R.M. (2007), "Why do countries matter so much for corporate governance", Journal of Financial Economics, Vol. 86 No. 1, pp. 1-39.

Dyreng, S.D. and Markle, K.S. (2016), "The effect of financial constraints on income shifting by U.S. Multinationals", The Accounting Review, Vol. 91 No. 6, pp. 1601-1627. 
Faccio, M. and Lang, L.H.P. (2002), "The ultimate ownership of Western European corporations", Journal of Financial Economics, Vol. 65 No. 3, pp. 365-395.

Fan, J.P.H. and Wong, T.J. (2002), "Corporate ownership structure and the informativeness of accounting earnings in East Asia", Journal of Accounting and Economics, Vol. 33, pp. 401-425.

Friedman, E., Johnson, S. and Mitton, T. (2003), "Propping and tunneling", Journal of Comparative Economics, Vol. 31 No. 4, pp. $732-750$.

Gomes, A. (2000), "Going public without Governance: managerial reputation effects", The Journal of Finance, Vol. LV No. 2, pp. 615-646.

Gong, G., Ke, B. and Yu, Y. (2013), "Home country investor protection, ownership structure and crosslisted firms' compliance with SOX-mandated internal control deficiency disclosures", Contemporary Accounting Research, Vol. 30 No. 4, pp. 1490-1523.

$\mathrm{Gu}$, J., Yang, Y. and Strange, R. (2018), "Location choice, ownership structure and multinational performance”, Multinational Business Review, Vol. 26 No. 3, pp. 250-276.

Hanlon, M. and Heitzman, S. (2010), “A review of tax research”, Journal of Accounting and Economics, Vol. 50 Nos 2-3, pp. 127-178.

Haw, I., Hu, B., Hwang, L.S. and Wu, W. (2004), "Ultimate ownership, income management, and legal and extra-legal institutions", Journal of Accounting Research, Vol. 42, pp. 423-462.

Hines, J.R. and Rice, E. (1994), "Fiscal paradise: foreign tax havens and american business", The Quarterly Journal of Economics, Vol. 109, pp. 149-182.

Hopland, A.O., Lisowsky, P., Mardan, M. and Schindler, D. (2018), "Flexibility in income shifting under losses", Accounting Review, Vol. 93 No. 3, pp. 163-183.

Huizinga, H. and Laeven, L. (2008), "International profit shifting within multinationals: a multi-country perspective”, Journal of Public Economics, Vol. 92, pp. 1164-1182.

Jacob, J. (1996), “Taxes and transfer pricing: income shifting and the volume of intrafirm transfers", Journal of Accounting Research, Vol. 34 No. 2, pp. 201-312.

Jensen, M. and Meckling, W. (1976), "Theory of the firm: managerial behavior, agency costs and ownership structure", Journal of Financial Economics, Vol. 3, pp. 305-360.

Jian, M. and Wong, T.J. (2010), "Propping through related party transactions", Review of Accounting Studies, Vol. 15 No. 1, pp. 70-105.

Johnson, S., Boone, P., Breach, A. and Friedman, E. (2000a), "Corporate governance in the Asian financial crisis", Journal of Financial Economics, Vol. 58 Nos 1-2, pp. 141-186.

Johnson, S., La Porta, R., Lopez-de-Silanes, F. and Shileifer, A. (2000b), "Tunneling”, The American Economic Review, Vol. 90 May, pp. 22-27.

Khan, M., Tan, L. and George, T. (2017), "Institutional ownership and corporate tax avoidance: new evidence", The Accounting Review, Vol. 92 No. 2, pp. 101-122.

Kim, K., Kitsabunnarat, P. and Nofsinger, J. (2007), "Large shareholders, board independence and small shareholders rights: evidence from Europe", Journal of Corporate Finance, Vol. 13, pp. 859-880.

Klassen, K.J. and Laplante, S.K. (2012), “Are US Multinational corporations becoming more aggressive income Shifters?”, Journal of Accounting Research, Vol. 50 No. 5, pp. 1245-1285.

Klassen, K., Lang, M. and Wolfson, M. (1993), "Geographic income shifting by multinational corporations in response to tax rate changes", Journal of Accounting Research, Vol. 31, pp. 141-173.

La Porta, R., Lopez-De-Silanes, F. and Shleifer, A. (1999), "Corporate ownership around the World", The Journal of Finance, Vol. 54 No. 2, pp. 471-517.

La Porta, R., Lopez-de-Silanes, F., Shleifer, A. and Vishny, R.W. (2000), "Agency problems and dividend policies around the World”, Journal of Finance, Vol. 55 No. 1, pp. 1-33.

La Porta, R., Lopez-de-Silanes, F. and Shleifer, A. (2008), "The economic consequences of legal origins", Journal of Economic Literature, Vol. 46 No. 2, pp. 285-332. 
$\mathrm{MD}$

58,12

2636
Lemmon, M.L. and Lins, K.V. (2003), "Ownership structure, corporate governance, and firm value: evidence from the East asian financial crisis", Journal of Finance, Vol. 58 No. 4, pp. 1445-1468.

Lim, Y. (2011), "Tax avoidance, cost of debt and shareholder activism: evidence from Korea”, Journal of Banking and Finance, Vol. 35, pp. 456-470.

Lins, K. (2003), "Equity ownership and firm value in emerging markets", Journal of Financial and Quantitative Analysis, Vol. 38 No. 1, pp. 159-184.

Markle, K. (2016), "A comparison of the tax-motivated income shifting of multinationals in territorial and worldwide countries", Contemporary Accounting Research, Vol. 33 No. 1, pp. 7-43.

Mcguire, S.T. and Wilson, R.J. (2014), "Dual class ownership and tax avoidance", The Accounting Review, Vol. 89 No. 4, pp. 1487-1516.

McGuire, S.T., Rane, S.G. and Weaver, C.D. (2018), "Internal information quality and tax-motivated income shifting", Journal of American Taxation Association, Vol. 40 No. 2, pp. 25-44.

Morck, R., Wolfenzon, D. and Yeung, B. (2005), "Corporate governance, economic entrenchment and growth", Journal of Economic Literature, Vol. 43 No. 3, pp. 655-720.

Nenova, T. (2003), "The value of corporate voting rights and control: a cross-country analysis", Journal of Financial Economics, Vol. 68 No. 3, pp. 325-351.

Rego, S. and Wilson, R. (2012), "Executive compensation, equity risk incentives, and corporate tax aggressiveness", Journal of Accounting Research, Vol. 50 No. 3, pp. 775-809.

Richardson, G., Wang, B. and Zhang, X. (2016), "Ownership structure and corporate tax avoidance: evidence from publicly listed private firms in China", Journal of Contemporary Accounting and Economics, Vol. 12, pp. 141-158.

Riyanto, Y.E. and Toolsema, L.A. (2008), "Tunneling and propping: a justification for pyramidal ownership", Journal of Banking and Finance, Vol. 32, pp. 2178-2187.

Shleifer, A. and Vishny, R. (1986), "Large shareholders and corporate control", Journal of Political Economy, Vol. 94 No. 3, pp. 461-488.

Shukla, D.M. and Akbar, M. (2018), "Diffusion of internationalization in business group networks: evidence from India”, Management Decision, Vol. 56 No. 2, pp. 406-420.

Williamson, O. (1985), The Economic Institutions of Capitalism, Free Press, New York.

Young, M.N., Peng, M.W., Ahlstrom, D., Bruton, G.D. and Jiang, Y. (2008), "Corporate governance in emerging economies: a review of the principal-principal perspective", Journal of Management Studies, Vol. 45 No. 1, pp. 196-220. 
Appendix

Variable definitions

Dependent variables

PBT

$\ln (\mathrm{PBT})$

Independent variables

Ownership

subsidiaries

$C$ tax foreign

subsidiaries

Tangible Assets

$\ln$ (Tangible Assets)

CompExp

$\ln$ (CompExp)

GDP

$\ln (\mathrm{GDP})$

Minority protection

index
Profit before income tax expense of the subsidiary-year in thousands of euro

Natural logarithm of profit before income tax expense of the subsidiary-year $\frac{1 \sum_{k \neq \neq i \frac{1}{1-y_{k}}}^{n}\left(y_{i}-y_{k}\right)}{1-y_{i}}$

where

$\gamma_{i}$ is the percentage of control (voting rights) of subsidiary $i$

$\gamma_{k}$ is the percentage of control (voting rights) of subsidiary $k$, where $k$ runs from 1 to $n$, where $n$ is the number of subsidiaries controlled by the parent

$B_{k}$ is the true profit of subsidiary $k$. Revenue is used as a proxy

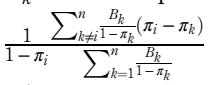

where

$\pi_{i}$ is the statutory tax rate of subsidiary $i$

$\pi_{k}$ is the statutory tax rate of subsidiary $k$, where $k$ runs from 1 to $n$, where $n$ is the number of subsidiaries controlled by the parent

$B_{k}$ is the true profit of subsidiary $k$. Revenue is used as a proxy

$\pi$ statutory tax rate comes from Worldwide Corporate Tax Guide developed every year by Ernst \& Young

Tangible fixed assets reported by the subsidiary in thousands of euro

Natural logarithm of tangible fixed assets reported by the subsidiary

Labor compensation reported by the subsidiary in thousands of euro

Natural logarithm of labor compensation reported by the subsidiary

Per capita GDP in the subsidiaries' country

Natural logarithm of per capita GDP in the subsidiaries' country

The Global Competitiveness Index has 12 pillars

Pillar 1 - Institutions includes

1. Public Institutions

2. Private Institutions

Private Institutions includes

1. Corporate ethics

2. Accountability

Accountability includes

1. Strength of auditing and reporting standards

2. Efficacy of corporate boards

3. Protection of minority shareholder interests

4. Strength of investor protection

Protection of minority shareholder interests is the answer to the following

question: "In your country, to what extent are the interests of minority

shareholders protected by the legal system? $[1=$ not protected at all; $7=$ fully

protected]". World Economic Forum, Executive Opinion Survey

\section{Corresponding author}

Alice Medioli can be contacted at: alice.medioli@unipr.it

For instructions on how to order reprints of this article, please visit our website:

www.emeraldgrouppublishing.com/licensing/reprints.htm

Or contact us for further details: permissions@emeraldinsight.com 